\title{
Role of fesoterodine in the treatment of overactive bladder
}

\author{
This article was published in the following Dove Press journal: \\ Open Access Journal of Urology \\ 17 December 2009 \\ Number of times this article has been viewed
}

\section{Kylie J Mansfield}

Graduate School of Medicine, University of Wollongong, NSW, Australia
Correspondence: Kylie Mansfield Graduate School of Medicine, University of Wollongong, Northfields Ave, Wollongong, 2522, NSW, Australia Email kylie@uow.edu.au

\begin{abstract}
Muscarinic receptors have long been the target receptors for treatment of patients with overactive bladder $(\mathrm{OAB})$. These patients experience symptoms of urgency, urinary frequency and nocturia, with or without urge incontinence (the involuntary leakage of urine associated with urge). Fesoterodine, a pro-drug, structurally and functionally related to tolterodine, is the newest agent developed for the treatment of OAB. Fesoterodine is broken down to the active metabolite, 5-hydroxy-methyl-tolterodine (5-HMT) by non-specific esterases. This metabolism results in the complete breakdown of the parent compound and is responsible for dose related improvements in clinical efficacy and health related quality of life. Like other antimuscarinic agents including tolterodine, fesoterodine is associated with improvements in clinical variables related both to bladder filling (decreasing micturition frequency and increasing mean voided volume) and urgency (urgency and urge incontinence episodes). Improvements in health related quality of life following treatment with fesoterodine is indicated by improvements in 7 of the 9 variables measured by the King's Health Questionnaire. Also like other antimuscarinic agents, fesoterodine use is associated with adverse events including dry mouth. However the incidence of dry mouth is reduced with fesoterodine, compared to oxybutynin, due to the improved bladder selectivity of 5-HMT.
\end{abstract}

Keywords: fesoterodine, 5-hydroxymethyl-tolterodine, muscarinic, overactive bladder, urgency, incontinence

\section{Overview of the overactive bladder}

Overactive bladder (OAB) is a debilitating chronic disorder experienced by approximately $17 \%$ of both men and women over the age of 40 years, with the prevalence increasing with increasing age. ${ }^{1,2}$ Patients with OAB typically experience symptoms of urgency, usually with frequency and nocturia, with or without urge incontinence (the involuntary leakage of urine associated with urge). ${ }^{3}$ Results from the National Overactive Bladder Evaluation (NOBEL) Programme conducted in the US indicated that $\mathrm{OAB}$ was more prevalent than other chronic conditions such as heart disease, sinusitis, and asthma. ${ }^{2}$

$\mathrm{OAB}$ is a chronic disease with a major negative influence on quality of life, especially associated with the limitations it places on physical and emotional roles, vitality and social functioning. ${ }^{4}$ The symptoms of OAB affect all aspects of life including: social (limiting outings due to frequent need to urinate), psychological (loss of self esteem associated with incontinence), physical (limitations of physical activities due to fear of incontinence) and occupational (decreased productivity). ${ }^{3}$ OAB can also be associated with economic costs including; the personal costs of managing submit your manuscript | www.dovepress.com

Dovepress
Open Access Journal of Urology 2010:2 I-9

(C) 2010 Mansfield, publisher and licensee Dove Medical Press Ltd.This is an Open Access article which permits unrestricted noncommercial use, provided the original work is properly cited. 
incontinence, the treatment costs associated with managing symptoms and providing care for incontinent nursing home residents and costs associated with decreased work productivity. In the US, the economic costs associated with OAB in the year 2000, were estimated to be between US\$12.02 billion and US $\$ 17.5$ billion. ${ }^{5}$ This makes the economic impact of OAB, comparable to the economic impact of influenza, arthritis and osteoarthritis. ${ }^{5}$

The cornerstone symptom of OAB is urgency ${ }^{1,6}$ which is defined as the complaint of a sudden compelling desire to pass urine which is difficult to defer. ${ }^{3}$ This symptom is associated with frequency of urination and nocturia. Approximately $66 \%$ of patients with $\mathrm{OAB}$ do not have urge incontinence and are classified as $\mathrm{OAB}$ dry. ${ }^{2}$ The remaining $33 \%$ of patients with OAB have urgency associated with incontinence and are classified as $\mathrm{OAB}$ wet. ${ }^{2}$ Urodynamic testing demonstrates that patients with $\mathrm{OAB}$ wet have detrusor overactivity, where urine leakage arises from involuntary detrusor contraction. ${ }^{3}$ The etiology of these involuntary detrusor contractions remains uncertain.

There are numerous treatment options available for patients with OAB including biofeedback, electrical stimulation, bladder training and pharmacotherapy, either alone or in combination. However, the primary treatment for the $\mathrm{OAB}$ is pharmacotherapy with muscarinic receptor antagonists $^{7-9}$ which have been used for many years. Oxybutynin $\left(\right.$ Ditropan $^{\circledR}$ ) was the first muscarinic receptor antagonist to be introduced to OAB therapy. Newer antimuscarinic agents include the $\mathrm{M}_{3}$ selective antagonists, darifenacin $\left(\right.$ Enablex $\left.{ }^{\circledR}\right)$ and solifenacin (VESIcare) and the relatively non-subtype selective antagonists, tolterodine $\left(\right.$ Detrol $\left.^{\circledR}\right)$ and its related compound fesoterodine $\left(\right.$ Toviaz $^{\circledR}$ ), which has only been recently introduced.

\section{The role of muscarinic receptors in bladder physiology}

The traditional dogma behind the treatment of OAB with muscarinic receptor antagonists was based on our understanding of the nerves controlling the physiological functions of the bladder. During filling the bladder detrusor muscle expands at low pressure. During this time the stretch of the bladder wall initiates the release of mediators (such as ATP) from the urothelium that signals bladder fullness via the underlying afferent nerves. ${ }^{10}$ Signals from these afferent nerves are processed in the Pontine micturition centre in the brain and, at an appropriate time, efferent parasympathetic nerves are activated. The efferent parasympathetic nerves release acetylcholine onto muscarinic receptors located on the detrusor muscle. ${ }^{11}$
There are 5 individual subtypes of muscarinic receptors $\left(\mathrm{M}_{1}-\mathrm{M}_{5}\right)$ that have been cloned and pharmacologically characterized. ${ }^{12}$ In the urinary bladder, as in other smooth muscles, multiple muscarinic receptor subtypes have been identified. ${ }^{13}$ Binding and immunoprecipitation studies, ${ }^{14-17}$ have demonstrated that the majority of muscarinic receptors present in human detrusor muscle, are $\mathrm{M}_{2}$ receptor $(\sim 70 \%)$ with smaller populations of $M_{3}(20 \%)$ and $M_{1}$ (10\%) receptors. ${ }^{17}$ Activation of muscarinic receptors by acetylcholine leads to contraction of the detrusor muscle and subsequent emptying of the bladder. Functional studies carried out in $\mathrm{M}_{3}$ knockout mice ${ }^{18}$ and human detrusor strips ${ }^{19,20}$ have demonstrated that muscarinic $\mathrm{M}_{3}$ receptors are the receptor subtype responsible for contraction of the detrusor muscle. Nevertheless, there is some evidence that $\mathrm{M}_{2}$ receptors also have some functional importance. ${ }^{21,22}$ Traditionally the muscarinic antagonists used to treat $\mathrm{OAB}$ were thought to inhibit activation of the muscarinic receptors responsible for detrusor contractions. Since both muscarinic $\mathrm{M}_{2}$ and $\mathrm{M}_{3}$ receptor subtypes are associated with detrusor contraction, muscarinic receptor antagonists, have been characterized according to their affinity for these receptor subtypes.

\section{Antimuscarinic therapy for $O A B$}

OAB therapy began when oxybutynin was shown to reduce contractions of the rabbit detrusor in response to the muscarinic agonist carbachol ${ }^{23}$ although oxybutynin is not selective for any individual muscarinic receptor subtype (Table 1). Oxybutynin was then shown to be clinically effective at preventing detrusor spasms following transurethral surgery ${ }^{24}$ which provided the impetus for antimuscarinic therapy for OAB. This was soon followed in the early 1980 s with reports of oxybutynin providing symptomatic relief for patients with detrusor instability. ${ }^{25,26}$

In 1998 tolterodine, another muscarinic receptor antagonist was first introduced. Like oxybutynin, toltero-

Table I Range of Ki values (in $\mathrm{nM}$ ) reported for antimuscarinic agents in cell lines expressing human muscarinic receptor subtypes

\begin{tabular}{llllll}
\hline Compound & $\mathbf{M}_{1}$ & $\mathbf{M}_{2}$ & $\mathbf{M}_{3}$ & $\mathbf{M}_{4}$ & $\mathbf{M}_{5}$ \\
\hline Oxybutynin $^{\mathrm{a}}$ & 4.5 & 36.5 & 3.3 & 5.2 & 19.6 \\
Tolterodine $^{\mathrm{b}}$ & 6.9 & 6.7 & 6.4 & 6.8 & 5.9 \\
Fesoterodine $^{\mathrm{c}}$ & 11.9 & 5.1 & 26.9 & 8.9 & 4.5 \\
5-HMT $^{\mathrm{d}}$ & 5.9 & 5.6 & 5.7 & 5.8 & 6.1 \\
\hline
\end{tabular}

aData summarized from ${ }^{36,85-89}$

${ }^{\text {bData summarized from }}{ }^{27,87-92}$

'Data summarized from ${ }^{36,92}$

dData summarized from ${ }^{27,36}$ 
dine, is relatively non-selective for individual muscarinic receptor subtypes (Table $1, \mathrm{Ki}$ at $\mathrm{M}_{3}$ and $\mathrm{M}_{2}$ receptors of 6.4 $\mathrm{nM}$ and $6.7 \mathrm{nM}$ respectively). ${ }^{27}$ And also like oxybutynin, tolterodine is efficacious in the treatment of OAB. ${ }^{28-32}$ However, the clinical efficacy of tolterodine has been demonstrated to be associated both with tolterodine itself, and with the generation of an active metabolite, 5-hydroxymethyl-tolterodine (5-HMT). ${ }^{33-35}$ Like tolterodine, 5-HMT demonstrates similar affinity for the individual muscarinic receptor subtypes (Table $1 \mathrm{Ki}$ at $\mathrm{M}_{3}$ and $\mathrm{M}_{2}$ receptors of $5.7 \mathrm{nM}$ and $5.6 \mathrm{nM}$ respectively). ${ }^{27,36}$ The newest muscarinic antagonist for therapy of OAB is fesoterodine. Fesoterodine, which is structurally related to tolterodine, also results in the formation of the same active metabolite, $5-\mathrm{HMT}^{37,38}$ although the mechanism underlying production of 5-HMT are vastly different.

\section{Pharmacokinetics of fesoterodine and tolterodine}

The active metabolite of tolterodine, 5-HMT, is formed by cytochrome P450 2D6 (CYP2D6) ${ }^{34}$ (Figure 1) which is subject to polymorphism. ${ }^{39}$ The polymorphism of CYP2D6 is highly clinical relevant as it is responsible for variability in metabolism of more than 100 different drugs. ${ }^{40}$ Based on their
CYP2D6 phenotype patients are characterized as extensive metabolizers, if they have two functional CYP2D6 alleles, or poor metbaolizers who lack functional CYP2D6 alleles. ${ }^{40} \mathrm{Up}$ to $10 \%$ of white populations and $19 \%$ of black populations are characterized as poor metabolizers. ${ }^{40}$ In patients classified as extensive metabolizers, $81 \%$ of the absorbed tolterodine, is extracted during first pass metabolism through the liver, ${ }^{39}$ and hydrolyzed to 5-HMT with an average maximal plasma concentration of tolterodine and 5-HMT being similar (5.2 and 4.8 $\mathrm{ng} / \mathrm{mL}$ respectively). ${ }^{39}$ In contrast, in poor metabolizers only $18 \%$ of tolterodine is extracted during first pass metabolism through the liver ${ }^{39}$ and the average maximal plasma concentration of tolterodine of is increased to $38 \mathrm{ng} / \mathrm{mL}$ while 5 -HMT is not detectable. ${ }^{39}$ Furthermore the concentration of 5-HMT released from metabolism of tolterodine is highly variable ( 1 to $100 \mathrm{ng} / \mathrm{mL})^{41}$ and this variability in the generation of the active metabolite makes individual tailoring of tolterodine dose necessary in some patients. ${ }^{39}$

Fesoterodine has been developed as a sustained release preparation with maximal plasma concentrations of 5-HMT detected approximately 4 to 6 hours after oral administration. ${ }^{42}$ In contrast to tolterodine, the formation of the active metabolite from fesoterodine is not dependent on CYP2D6 activity (Figure 1) but rather occurs due to hydrolysis of fesoterodine<smiles>CC(C)OC(=O)Oc1ccc(CO)cc1[C@H](CCCN(C(C)C)C(C)C)c1ccccc1</smiles>

non-specific
esterases<smiles>Cc1ccc(O)c(C(CCN(C(C)C)C(C)C)c2ccccc2)c1</smiles>

Tolterodine

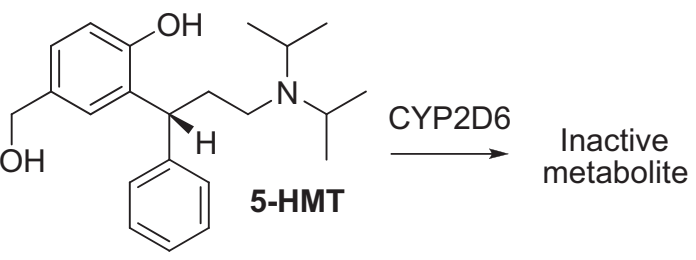<smiles>[R15][AsH2]</smiles>

Inactive

metabolite

Figure I Metabolic pathways responsible for the generation of 5-hydroxymethyl-tolterodine (5-HMT) from tolterodine and fesoterodine. 
by non-specific esterases. No fesoterodine is detected in the plasma of patients indicating that metabolism of fesoterodine is rapid and complete. ${ }^{41,43}$ Also, in contrast to tolterodine, there is little inter-subject variability in the generation of 5-HMT from fesoterodine, as the activity of the non-specific esterases is similar in all people. ${ }^{37,44}$ Oral administration of a single dose of $4 \mathrm{mg}$ fesoterodine, results in a maximal plasma concentration of 5-HMT between 1 and $10 \mathrm{ng} / \mathrm{mL},{ }^{41,45}$ with plasma concentrations of 5-HMT overlapping in patients characterized as extensive ( 0.9 to $5.6 \mathrm{ng} / \mathrm{mL})$ or poor metabolizers $(2.0$ to $10.9 \mathrm{ng} / \mathrm{mL}) .{ }^{41}$ In addition, plasma concentrations of 5-HMT increases linearly with increasing fesoterodine dose. ${ }^{41} \mathrm{~A}$ large proportion of the active metabolite, 5-HMT, is transported in the plasma unbound (36 to $54 \%$ ), ${ }^{39,42}$ in contrast to tolterodine which is almost entirely bound to serum albumin (3.7\% unbound). ${ }^{39}$

Breakdown of 5-HMT, generated from either tolterodine or fesoterodine, to inactive metabolites occurs via cytochrome P450 3A4 and CYP2D6 (Figure 1) and is therefore varied in extensive and poor metabolizers. ${ }^{45,46}$ Approximately $70 \%$ of the fesoterodine dose is eliminated via the urine with approximately $16 \%$ being eliminated as $5-\mathrm{HMT}^{42}$ the rest as inactive metabolites. ${ }^{43}$ The urine elimination of 5-HMT increasing proportionally with fesoterodine dose. ${ }^{43}$ Excretion of 5-HMT is slowed in patients with renal impairment, however this delay in excretion was not associated with a significant increase in adverse events in these patients. ${ }^{42}$

\section{Efficacy of fesoterodine and tolterodine in clinical trials}

Both fesoterodine and tolterodine have been associated with clinical efficacy that exceeds placebo in a number of important clinical variables. Four recent randomized controlled trials have compared the clinical efficacy of fesoterodine with placebo, ${ }^{37,47-49}$ two of which also compared fesoterodine with tolterodine. ${ }^{47,49}$ Selected results from these clinical trials are summarized in Table 2. These results indicate that both fesoterodine and tolterodine have clinical efficacy against symptoms related to bladder filling (micturition frequency and mean voided volume) and urgency (urgency episodes, urge incontinence episodes).

In regards to symptoms related to bladder filling, treatment for 12 weeks with a once daily dose of fesoterodine (4 mg) resulted in a significant decrease in micturition frequency $(5.5 \%$ greater than the average placebo effect) which corresponds to 1.7 less micturitions per 24 hours. Fesoterodine (4 mg) was also associated with an increase in mean voided volume of $25.1 \mathrm{~mL}$ compared to an average increase in placebo of $9.3 \mathrm{~mL}$. These changes in clinical outcomes with $4 \mathrm{mg}$ fesoterodine were comparable to tolterodine (4 mg) (Table 2). ${ }^{47,49}$

Fesoterodine was also effective against symptoms related to urgency. Treatment with $4 \mathrm{mg}$ fesoterodine resulted in a significant decrease in urge incontinence episodes and urgency episodes. In OAB wet patients the decrease in urge incontinence episodes was $26.6 \%$ greater than the average placebo effect; that is 1.9 less episodes of urge incontinence per 24 hours (Table 2). In addition there was a significant decrease in urgency episodes which was $8.2 \%$ greater than the average placebo effect (Table 2). This corresponds to 2 less urgency episodes per 24 hours. ${ }^{37,47-49}$

One interesting feature of fesoterodine treatment is that the improvements in clinical efficacy are shown to be

Table 2 Efficacy of fesoterodine and tolterodine in 12 week clinical trials for OAB therapy

\begin{tabular}{|c|c|c|c|c|c|}
\hline & \multirow{2}{*}{$\begin{array}{l}\text { Range of } \\
\text { baseline values }\end{array}$} & \multirow[t]{2}{*}{ Placebo $^{\mathrm{a}, \mathrm{b}}$} & \multicolumn{2}{|c|}{ Fesoterodine $^{a}$} & \multirow{2}{*}{$\frac{\text { Tolterodine } \mathbf{E R}^{\mathrm{b}}}{4 \mathrm{mg}}$} \\
\hline & & & $4 \mathrm{mg}$ & $8 \mathrm{mg}$ & \\
\hline Micturition frequency & $11.5-12.9$ & $-9.3 \%$ & $-15.5 \% *,+$ & $-16.9 \% *,+$ & $-15.6 \% *$ \\
\hline MVV (mL) & $150-160$ & +9.04 & $+23.0 *, \dagger$ & $+33.2^{*,+, * *}$ & $+25.1 *$ \\
\hline Urgency episodes & $11-12.5$ & $-7.5 \%$ & $-16.9 \% *,+$ & $-18.8 \% *, \dagger$ & $-17.5 \% *$ \\
\hline UUl episodes & $3.7-4.0$ & $-40.7 \%$ & $-67.5 \% *,+$ & $-77.9 \% *,+, * *$ & $-56.3 \%$ \\
\hline Continent days/week & $0.6-0.8$ & +1.7 & $+2.6 *, \dagger$ & $+3.0^{*,+, * *}$ & $+2.6^{*}$ \\
\hline
\end{tabular}

Notes: Statistical significance reported: ${ }^{P} P<0.05$ vs placebo, ${ }^{\dagger} P<0.001$ vs placebo and ${ }^{\text {wh }} P<0.05$ vs 4 mg fesoterodine treatment.

Definition of measures:

Micturition frequency is the number of times a patient passed urine (including incontinence episodes) in a 24-hour period.

$\mathrm{MVV}$ is the mean voided volume $(\mathrm{mL})$ per micturition determined from a I-day collection period.

Urgency episodes is the number of times a patient recorded an urgency episode with or without incontinence per day determined from a 3-day bladder diary.

Urge urinary incontinence is the number of times the patient experiences involuntary leakage of urine accompanied by or immediately preceded by urgency in a 24 -hour period determined from a 3-day bladder diary.

Continent days per week were normalized from a 3-day bladder diary.

aData summarized from ${ }^{37,47-49}$

bData summarized from ${ }^{47,49}$ 
increased with increasing dose (8 $\mathrm{mg}$ compared to $4 \mathrm{mg}$ ) (Table 2). Treatment with $8 \mathrm{mg}$ fesoterodine resulted in a significantly greater decrease in urge incontinence episodes per 24 hours $(9.1 \%$ greater than the average decrease with $4 \mathrm{mg}$ fesoterodine), together with an increase in mean voided volume $(8 \mathrm{~mL}$ greater than the average improvement with $4 \mathrm{mg}$ fesoterodine). In addition, treatment with $8 \mathrm{mg}$ fesoterodine was also associated with an increase in the number of continent days per week to 3.1 days compared to 2.7 days with fesoterodine $4 \mathrm{mg} .{ }^{47-49}$

Fesoterodine is unusual in showing this dose response relationship as a similar relationship has not been demonstrated for other antimuscarinic agents including tolterodine, ${ }^{50-52}$ or the muscarinic $\mathrm{M}_{3}$ receptors selective agents, darifenacin ${ }^{53}$ and solifenacin. ${ }^{54}$ It is likely that this dose response relationship is a result of the simple metabolism of fesoterodine by the non-specific esterases and the associated linear relationship between fesoterodine dose and plasma concentrations of the active compound, 5-HMT. ${ }^{41,43}$

In addition to the improvements in clinical outcomes fesoterodine has also been associated with improvements in Health Related Quality of life (HRQoL). The King's Health Questionnaire, which examines 9 domains related to quality of life, ${ }^{55}$ has been used to assess improvements in HRQoL in people who suffer from OAB following 12 week treatment with fesoterodine. ${ }^{56,57}$ Significant improvement in five or more domains of the King's Health Questionnaire is considered to indicate meaningful improvement in patient quality of life. ${ }^{58}$ Similar to clinical efficacy, improvements in HRQoL were related to fesoterodine dose. Treatment with $8 \mathrm{mg}$ fesoterodine showed significant improvements (compared with placebo) in 8 of the 9 domains assessed by the King's Health Questionnaire. While $4 \mathrm{mg}$ fesoterodine (and tolterodine $4 \mathrm{mg}$ ), showed significant improvements (compared with placebo) in 7 of the 9 domains. ${ }^{59}$ The domains where fesoterodine was associated with improvement include: severity/coping, emotions, role limitations, physical limitations, social limitations, sleep/energy, personal relationship and incontinence impact. ${ }^{56,57}$ Of these improvements all except benefit for personal relationship were seen in patients who were classified as both $\mathrm{OAB}$ wet and OAB dry. ${ }^{56}$ Treatment with $8 \mathrm{mg}$ fesoterodine also showed significantly greater improvement compared to $4 \mathrm{mg}$ fesoterodine in domains of severity/coping and emotions..$^{57}$

\section{Adverse events associated with fesoterodine and tolterodine}

While muscarinic antagonists can be used to effectively treat $\mathrm{OAB}$ in approximately $65 \%$ of patients, numerous patients discontinue therapy long term due to adverse events including dry mouth and constipation. ${ }^{59}$ These adverse events occur due to a lack of organ selectivity of antimuscarinic agents ${ }^{60}$ as muscarinic receptors are not only located on the detrusor muscle but also in the salivary glands ${ }^{61}$ and smooth muscle of the gastrointestinal tract. ${ }^{13,62}$ The incidence of these adverse events in clinical trials of fesoterodine and tolterodine are summarized in Table 3..$^{37,47-49}$

Dry mouth was the most common adverse event associated with fesoterodine use (Table 3), although most patients described it as mild to moderate. Twenty percent of patients being treated with $4 \mathrm{mg}$ fesoterodine reported dry mouth. ${ }^{37,47-49,63}$ This was increased to $35 \%$ in patients being treated with $8 \mathrm{mg}$ fesoterodine ${ }^{37,47-49}$ compared to an incidence of $6 \%$ in placebo (Table 3). Although common, dry mouth did not account for a large number of patients withdrawing from the 12 week clinical trials (Table 3 ). The incidence of dry mouth with fesoterodine $(4 \mathrm{mg}$ ) was comparable to the incidence in patients treated with tolterodine $(4 \mathrm{mg})^{30,47,49,64}$ however it was considerably lower than that reported with oxybutynin (Table 3)..$^{30,65}$

The reason for the decrease in incidence of dry mouth with fesoterodine (and tolterodine) compared to oxybutynin may lie in the selectivity of 5-HMT for the bladder over the salivary gland (Table 4). Radiologand binding studies in

Table 3 Incidence of dry mouth and constipation in patients treated with oxybutynin, tolterodine, and fesoterodine

\begin{tabular}{llllll}
\hline & Antimuscarinic dose & Dry mouth & Constipation & $\begin{array}{l}\text { Discontinuation due } \\
\text { to adverse events }\end{array}$ & Reference \\
\hline Oxybutynin & 5 and $10 \mathrm{mg}$ & $32.9 \%$ & $7.3 \%$ & $1.8 \%$ & Data summarized from $^{30,65}$ \\
Tolterodine ER & $4 \mathrm{mg}$ & $19.8 \%$ & $4 \%$ & $2.5 \%$ & Data summarized from $^{30,47,49,64}$ \\
Fesoterodine & $4 \mathrm{mg}$ & $20.2 \%$ & $4.4 \%$ & $5 \%$ & Data summarized from $^{37,47-49,63}$ \\
Fesoterodine & $8 \mathrm{mg}$ & $34.7 \%$ & $5.1 \%$ & $6.8 \%$ & Data summarized from $^{37,47-49}$ \\
Placebo & & $4.9 \%$ & $2.5 \%$ & $3.1 \%$ & Data summarized from $^{37,47-49,65}$ \\
\hline
\end{tabular}


Table 4 Selectivity of antimuscarinic agents for bladder and salivary gland as determined by radioligand binding and in vivo functional studies

\begin{tabular}{|c|c|c|c|c|c|}
\hline \multirow[t]{3}{*}{ Compound } & \multirow{2}{*}{\multicolumn{2}{|c|}{$\begin{array}{l}\text { Radioligand binding studies } \\
\mathbf{K i}(\mathrm{nM})\end{array}$}} & \multicolumn{3}{|c|}{ In vivo functional studies } \\
\hline & & & \multicolumn{3}{|c|}{$I_{50}(\mathrm{nmol} / \mathrm{kg} \mathrm{iv})^{\mathrm{a}}$} \\
\hline & Bladder & Salivary gland & Bladder & Salivary gland & Reference \\
\hline Oxybutynin & 9.8 & 3.02 & 215 & 76 & Data summarized from ${ }^{66,86,93}$ \\
\hline Tolterodine & 2.7 & 4.8 & 101 & 257 & Data summarized from ${ }^{66,90,91}$ \\
\hline 5-HMT & 2.9 & 5.2 & 15 & 40 & Data summarized from ${ }^{27}$ \\
\hline
\end{tabular}

Note: data are not available for fesoterodine as it is completely metabolized to 5-HMT.

${ }^{a} D_{50}$ determined from in vivo functional studies where antagonists were infused into anesthetized animals. Bladder contraction was stimulated by intra-arterial acetylcholine. Salivation was stimulated by electrical stimulation of the chorda-lingual nerve. ${ }^{27,66,91}$

salivary gland and bladder have demonstrated that oxybutynin has a three times higher affinity for salivary gland over the bladder (Table 4). In contrast tolterodine and 5-HMT have an affinity for the bladder that is twice that for the salivary gland (Table 4). Further to this, functional studies have examined the selectivity of oxybutynin, tolterodine and 5-HMT, for the bladder and salivary gland by comparing the concentrations required to inhibit detrusor contractions and salivation in vivo. Similar to the results from radioligand binding studies, oxybutynin inhibits salivation at a concentration that is approximately one-third lower than that required to inhibit bladder contraction (Table 4) indicating some degree of selectivity for the salivary gland. ${ }^{66}$ In contrast, 5-HMT inhibits bladder contractions at a lower concentration than that required to inhibit salivation ${ }^{27}$ indicating some degree of selectivity for the bladder. The reasons for this bladder selectivity of 5-HMT is unknown and cannot be explained simply by selectivity for individual muscarinic receptor subtypes.

\section{Antimuscarinic agents show clinical efficacy against the symptom of urgency}

Fesoterodine and tolterodine have demonstrated efficacy against symptoms of urgency as demonstrated by improvements in the clinical variables of urge incontinence episodes and urgency episodes per 24 hours (Table 2)..$^{37,47-49,67}$ This is similar to reports from clinical trials with other muscarinic receptor antagonists, including the $\mathrm{M}_{3}$ selective agent solifenacin ${ }^{68-70}$ and trospium. ${ }^{71}$ However, these beneficial effects, on the symptoms of urgency, raises the question as to how urgency is sensed, what receptors are involved and why antimuscarinic agents are effective against urgency. Answering these questions and understanding how these antimuscarinic agents are efficacious against urgency is important, as urgency is the cornerstone symptom for $\mathrm{OAB}$ and the symptom that patients identify as their most bothersome. ${ }^{6}$
Recent reviews have suggested that at therapeutic doses, muscarinic antagonists do not appear to inhibit bladder contractility, ${ }^{8,72}$ and their activity is now thought to be during bladder filling to increase bladder capacity and to decrease urgency ${ }^{8}$ actions not attributable to inhibition of muscarinic receptors located on the detrusor.

Radioligand binding studies in both pig $^{73}$ and human bladder ${ }^{17}$ have demonstrated $\mathrm{M}_{2}(70 \%)$ and $\mathrm{M}_{3}(30 \%)$ muscarinic receptors in the bladder mucosa. Mucosal muscarinic receptors have also been demonstrated using molecular RT-PCR studies which demonstrate expression of mRNA for $\mathrm{M}_{1}, \mathrm{M}_{2}, \mathrm{M}_{3}$, and $\mathrm{M}_{5}{ }^{17,74,75}$ Immunohistochemical studies have localized muscarinic receptor immunoreactivity to the bladder urothelium ${ }^{74-76}$ and to suburothelial myofibroblasts. ${ }^{76,77}$ The role of these mucosal muscarinic receptors in bladder micturition remains unclear. However, they may represent a site of action for the muscarinic receptor antagonists used to treat OAB.

Recent, in vivo studies in rat bladder have demonstrated that intravesical administration of carbachol can induce detrusor overactivity ${ }^{78}$ where as intravesical instillation of muscarinic antagonists including oxybutynin, ${ }^{79}$ tolterodine ${ }^{80}$ and darifenacin ${ }^{81}$ reduces stretch activated afferent nerve firing in rat bladder, an effect also seen following systemic administration of oxybutynin. ${ }^{82}$ Furthermore, clinical efficacy has been associated, in patients with $\mathrm{OAB}$, with intravesical instillation of oxybutynin ${ }^{83,84}$ It is possible that following oral administration of fesoterodine or tolterodine the presence of the active metabolites, 5-HMT, in the urine as a result of urinary excretion is partly responsible for the clinical efficacy of these agents.

\section{Conclusion}

Fesoterodine is a pro-drug developed to produce the active metabolite, 5-hydroxy-methyl-tolterodine (5-HMT) via the actions of non-specific esterases. This metabolism of fesoterodine results in the complete breakdown of the parent 
compound and is responsible for dose related improvements in clinical efficacy and health related quality of life. Fesoterodine, like tolterodine and other antimuscarinic agents, has been shown to have clinical efficacy for the treatment of patients suffering from OAB. Treatment with fesoterodine is associated with improvements in clinical variables related both to bladder filling (decreasing micturition frequency and increasing mean voided volume) and urgency (urgency and urge incontinence episodes). Fesoterodine is also associated with significant improvements in health related quality of life as indicated by improvements in at least 7 of the 9 variables measured by the King's Health Questionnaire. Fesoterodine, like other antimuscarinic agents, is associated with adverse events such as dry mouth and constipation. However the incidence of these adverse events is reduced compared, to the original muscarinic antagonist oxybutynin, due to the improved bladder selectivity of 5-HMT.

\section{Disclosure}

The author declares no conflicts of interest.

\section{References}

1. Milsom I, Abrams P, Cardozo L, et al. How widespread are the symptoms of an overactive bladder and how are they managed? A population-based prevalence study. BJU Int. 2001;87(9):760-766.

2. Stewart WF, Van Rooyen JB, Cundiff GW, et al. Prevalence and burden of overactive bladder in the United States. World J Urol. 2003;20(6): 327-336.

3. Abrams P, Cardozo L, Fall M, et al; for Standardisation Sub-committee of the International Continence Society. The standardisation of terminology of lower urinary tract function: report from the Standardisation Sub-committee of the International Continence Society. Neurourol Urodyn. 2002;21(2):167-178.

4. Tubaro A. Defining overactive bladder: epidemiology and burden of disease. Urology. 2004;64(6 Suppl 1):2-6.

5. Hu TW, Wagner TH, Bentkover JD, et al. Estimated economic costs of overactive bladder in the United States. Urology. 2003;61(6): 1123-1128.

6. Brubaker L. Urgency: the cornerstone symptom of overactive bladder. Urology. 2004;64(6 Suppl 1):12-16.

7. Abrams P, Andersson KE. Muscarinic receptor antagonists for overactive bladder. BJU Int. 2007;100(5):987-1006.

8. Andersson KE, Yoshida M. Antimuscarinics and the overactive detrusor-which is the main mechanism of action? Eur Urol. 2003;43(1):1-5.

9. Hegde SS, Muscarinic receptors in the bladder: from basic research to therapeutics. Br J Pharmacol. 2006;147(Suppl 2):S80-S87.

10. Ferguson DR, Kennedy I, Burton TJ. ATP is released from rabbit urinary bladder epithelial cells by hydrostatic pressure changes - a possible sensory mechanism? J Physiol. 1997;505(2):503-511.

11. Downie JW, Dean DM. The contribution of cholinergic postganglionic neurotransmission to contractions of rabbit detrusor. J Pharmacol Exp Ther. 1977;203(2):417-425.

12. Caulfield MP, Birdsall NJ. International Union of Pharmacology. XVII. Classification of muscarinic acetylcholine receptors. Pharmacol Rev. 1998;50(2):279-290.
13. Eglen RM, Hegde S, Watson N. Muscarinic receptor subtypes and smooth muscle function. Pharmacol Rev. 1996;48(4):531-565.

14. Nilvebrant L, Andersson KE, Mattiasson A. Characterization of the muscarinic cholinoceptors in the human detrusor. J Urol. 1985;134(2): 418-423.

15. Wang P, Luthin GR, Ruggieri MR. Muscarinic acetylcholine receptor subtypes mediating urinary bladder contractility and coupling to GTP binding proteins. J Pharmacol Exp Ther. 1995;273(2):959-966.

16. Goepel M, Gronewald A, Krege S, et al. Muscarinic receptor subtypes in porcine detrusor: comparison with humans and regulation by bladder augmentation. Urol Res. 1998;26(2):149-154.

17. Mansfield KJ, Liu L, Mitchelson FJ, et al. Muscarinic receptor subtypes in human bladder detrusor and mucosa, studied by radioligand binding and quantitative competitive RT-PCR: changes in ageing. $\mathrm{Br} J$ Pharmacol. 2005;144(8):1089-1099.

18. Matsui M, Motomura D, Karasawa H, et al. Multiple functional defects in peripheral autonomic organs in mice lacking muscarinic acetylcholine receptor gene for the M3 subtype. Proc Nat Acad Sci U S A. 2000;97(17):9579-9584.

19. Chess-Williams R, Chapple CR, Yamanishi T, et al. The minor population of M3-receptors mediate contraction of human detrusor muscle in vitro. J Auton Pharmacol. 2001;21(5-6):243-248.

20. Fetscher C, Fleichman M, Schmidt M, et al. M(3) muscarinic receptors mediate contraction of human urinary bladder. Br J Pharmacol. 2002;136(5):641-643.

21. Matsui M, Motomura D, Fujikawa T, et al. Mice lacking M2 and M3 muscarinic acetylcholine receptors are devoid of cholinergic smooth muscle contractions but still viable. J Neurosci. 2002;22(24): 10627-10632.

22. Ehlert FJ. Contractile role of M2 and M3 muscarinic receptors in gastrointestinal, airway and urinary bladder smooth muscle. Life Sci. 2003;74(2-3):355-266.

23. Fredericks CM, Green RL, Anderson GF. Comparative in vitro effects of imipramine, oxybutynin, and flavoxate on rabbit detrusor. Urology. 1978;12(4):487-491.

24. Paulson DF. Oxybutynin chloride in control of post-trasurethral vesical pain and spasm. Urology. 1978;11(3):237-238.

25. Moisey CU, StephensonTP, Brendler CB. The urodynamic and subjective results of treatment of detrusor instability with oxybutynin chloride. Br J Urology. 1980;52(6):472-475.

26. Bary PR, Moisey CU, Stephenson TP, et al. The urodynamic and subjective results of treatment of detrusor instability with oxybutynin chloride. Prog Clin Biol Res. 1981;78:313-319.

27. Nilvebrant L, Gillberg PG, Sparf B. Antimuscarinic potency and bladder selectivity of PNU-200577, a major metabolite of tolterodine. Pharmacol Toxicol. 1997;81(4):169-172.

28. Van Kerrebroeck P, Kreder K, Jonas U, et al; for Tolterodine Study Group. Tolterodine once-daily: superior efficacy and tolerability in the treatment of the overactive bladder. Urology. 2001;57(3):414-421.

29. Sussman D, Garely A. Treatment of overactive bladder with oncedaily extended-release tolterodine or oxybutynin: the antimuscarinic clinical effectiveness trial (ACET). Cur Med Res Opin. 2002;18(4): 177-184.

30. Diokno AC, Appell RA, Sand PK, et al; for the OPERA Study Group., Prospective, randomized, double-blind study of the efficacy and tolerability of the extended-release formulations of oxybutynin and tolterodine for overactive bladder: results of the OPERA trial. Mayo Clin Proc. 2003;78(6):687-695.

31. Kaplan SA, Roehrborn CG, Dmochowski R, et al. Tolterodine extended release improves overactive bladder symptoms in men with overactive bladder and nocturia. Urology. 2006;68(2):328-332.

32. Dmochowski R, Abrams P, Marschall-Kehrel D, et al. Efficacy and tolerability of tolterodine extended release in male and female patients with overactive bladder. Eur Urol. 2007;51(4):1054-1064.

33. Andersson SH, Lindgren A, Postlind H. Biotransformation of tolterodine, a new muscarinic receptor antagonist, in mice, rats, and dogs. Drug Met Disp. 1998;26(6):528-535. 
34. Postlind HD, Lindgren A, Andersson SH. Tolterodine, a new muscarinic receptor antagonist, is metabolized by cytochromes P450 2D6 and 3A in human liver microsomes. Drug Met Disp. 1998;26(4):289-293.

35. Palmér L, Andersson L, Andersson T, et al. Determination of tolterodine and the 5-hydroxymethyl metabolite in plasma, serum and urine using gas chromatography-mass spectrometry. J Pharm Biomed Anal. 1997;16(1):155-165.

36. Ney P, Pandita RK, Newgreen DT, et al. Pharmacological characterization of a novel investigational antimuscarinic drug, fesoterodine, in vitro and in vivo. BJU Int. 2008;101(8):1036-1042.

37. Khullar V, Rovner ES, Dmochowski R, et al. Fesoterodine dose response in subjects with overactive bladder syndrome. Urology. 2008;71:839-843.

38. Michel MC, Hedge S. Treatment of the overactive bladder syndrome with muscarinic receptor antagonists: a matter of metabolites? Naunyn Schmiedebergs Arch Pharmacol. 2006;374(2):79-85.

39. Brynne N, Dalén P, Alván G, et al. Influence of CYP2D6 polymorphism on the pharmacokinetics and pharmacodynamic of tolterodine. Clin Pharmacol Ther. 1998;63(5):529-539.

40. Xie HG, Kim RB, Wood AJ, et al. Molecular basis of ethnic differences in drug disposition and response. Ann Rev Pharmacol Toxicol. 2001;41:851-850.

41. Simon HU, Malhotra B. The pharmacokinetic profile of fesoterodine: similarities and differences to tolterodine. Swiss Med Weekly. 2009;139(9-10):146-151.

42. Malhotra B, Gandelman K, Sachse R, et al. Assessment of the effects of renal impairment on the pharmacokinetic profile of fesoterodine. J Clin Pharmacol. 2009;49(4):477-482.

43. Sachse R, Cawello W, Haag C, et al. Pharmacodynamics and pharmacokinetics of ascending multiple doses of the novel bladder-selective antimuscarinic fesoterodine. Eur Urol. 2003;2(1):30.

44. Cawello W, Auer S, Hammes W, et al. Multiple dose pharmacokinetics of fesoterodine in human subjects. Naunyn-Schmiedeberg's Arch Pharmacol. 2002;365(Suppl 1):R110.

45. Malhotra B, Sachse R, Wood N. Evaluation of drug-drug interactions with fesoterodine. Eur J Clin Pharmacol. 2009;65(6):551-560.

46. Malhotra B, Guan Z, Wood N, et al. Pharmacokinetic profile of fesoterodine. Int $J$ Clin Pharmacol Ther. 2008;46(11):556-563.

47. Chapple C, V Kerrebroeck P, Tubaro A, et al. Clinical efficacy, safety, and tolerability of once-daily fesoterodine in subjects with overactive bladder. Eur Urol. 2007;52(4):1204-1212.

48. Nitti VW, Dmochowski R, Sand PK, et al. Efficacy, safety and tolerability of Fesoterodine for overactive bladder syndromes. $J$ Urol. 2007; 178:2488-2494.

49. Sand PK, Morrow J, Bavendam T, et al. Efficacy and tolerability of fesoterodine in women with overactive bladder. Int Urogynaecol J. 2009;20:827-835.

50. Larsson G, Hallén B, Nilvebrant L. Tolterodine in the treatment of overactive bladder: analysis of the pooled phase II efficacy and safety data. Urology. 1999;53(5):990-998.

51. Millard R, Tuttle J, Moore KH, et al. Clinical efficacy and safety of tolterodine compared to placebo in detrusor overactivity. $J$ Urol. 1999;161(5):1551-1555.

52. Van Kerrebroeck PE, Amarenco G, Thüroff JW, et al. Dose-ranging study of tolterodine in patients with detrusor hyperreflexia. Neurourol Urodyn. 1998;17(5):499-512.

53. Hill S, Khullar V, Wyndaele JJ, et al; for the Darifenacin Study Group. Dose response with darifenacin, a novel once-daily M3 selective receptor antagonist for the treatment of overactive bladder: results of a fixed dose study. Int Urogynecol J Pelvic Floor Dysfunct. 2006;17:239-247.

54. Cardozo L, Lisec M, Millard R, et al. Randomized, double-blind placebo controlled trial of the once daily antimuscarinic agent solifenacin succinate in patients with overactive bladder. $J$ Urol. 2004;172:1919-1924.

55. Kelleher CJ, Cardozo LD, Khullar V, et al. A new questionnaire to assess the quality of life of urinary incontinent women. $\mathrm{Br} J$ Obstet Gynaecol. 1997;104(12):1374-1279.
56. Chapple CR, Van Kerrebroeck P, Jünemann KP, et al. Comparison of fesoterodine and tolterodine in patients with overactive bladder. $B J U$ Int. 2008;102(9):1128-1132.

57. Kelleher CJ, Tubaro A, Wang JT, et al. Impact of fesoterodine on quality of life: pooled data from two randomized trials. BJU Int. 2008;102(1): $56-61$.

58. Kelleher CJ, Pleil A, Reese PR, et al. How much is enough and who says so? BJOG. 2004;111(6):605-612.

59. Morris AR, Westbrook J, Moore KH. A longitudinal study over 5 to 10 years of clinical outcomes in women with idiopathic detrusor overactivity. BJOG. 2008;115(2):239-246.

60. Colli E, Digesu G, Olivieri L. Overactive bladder treatments in early phase clinical trials. Exp Opin Invest Drugs. 2007;16(7):999-1007.

61. Martos F, Bermudez R, Gomez A, et al. Characterization of muscarinic receptors in human submandibular salivary glands. Eur J Pharmacol. 1985;116(3):319-321.

62. Mansfield KJ, Mitchelson F, Moore KH, et al. Muscarinic receptor subtypes in the human colon: lack of evidence for atypical subtypes. Eur J Pharmacol. 2004;482(1-3):101-109.

63. Wyndaele JJ, Goldfischer ER, Morrow JD, et al. Effects of flexible-dose fesoterodine on overactive bladder symptoms and treatment satisfaction: an open-label study. Int J Clin Pract. 2009;63(4):560-567.

64. Chapple CR, Fianu-Jonsson A, Indig M, et al; for the STAR study group. Treatment outcomes in the STAR study: a subanalysis of solifenacin $5 \mathrm{mg}$ and tolterodine ER $4 \mathrm{mg}$. Eur Urol. 2007;52(4):1195-1203.

65. Zinner N, Tuttle J, Marks L. Efficacy and tolerability of darifenacin, a muscarinic M3 selective receptor antagonist (M3 SRA), compared with oxybutynin in the treatment of patients with overactive bladder. World J Urol. 2005;23(4):248-252.

66. Nilvebrant L, Andersson KE, Gillberg PG, et al. Tolterodine - a new bladder-selective antimuscarinic agent. Eur J Pharmacol. 1997; 327(2-3):195-207.

67. Freeman R, Hill S, Millard R, et al; for the Tolterodine Study Group. Reduced perception of urgency in treatment of overactive bladder with extended-release tolterodine. Obstet Gynaecol. 2003;102(3): 605-611.

68. Chapple CR, Araño P, Bosch JL, et al. Solifenacin appears effective and well tolerated in patients with symptomatic idiopathic detrusor overactivity in a placebo- and tolterodine-controlled phase 2 dose-finding study. BJU Int. 2004;93(1):71-77.

69. Millard RJ, Halaska M. Efficacy of solifenacin in patients with severe symptoms of overactive bladder: a pooled analysis. Curr Med Res Opin. 2006;22(1):41-48.

70. Wagg A, Wyndaele JJ, Sieber P. Efficacy and tolerability of solifenacin in elderly subjects with overactive bladder syndrome: a pooled analysis. Am J Geriatr Pharmacother. 2006;4(1):14-24.

71. Zinner N, Gittelman M, Harris R, et al; for the Trospium Study Group. Trospium chloride improves overactive bladder symptoms: a multicenter phase III trial. J Urol. 2004;171(6 pt 1):2311-2315.

72. Finney SM, Andersson KE, Gillespie JI, et al. Antimuscarinic drugs in detrusor overactivity and the overactive bladder syndrome: motor or sensory actions? BJU Int. 2006;98(3):503-507.

73. Hawthorn MH, Chapple CR, Cock M, et al. Urothelium-derived inhibitory factor(s) influences on detrusor muscle contractility in vitro. $\mathrm{Br} \mathrm{J}$ Pharmacol. 2000;129(3):416-419.

74. Bschleipfer T, Schukowski K, Weidner W, et al. Expression and distribution of cholinergic receptors in the human urothelium. Life Sci. 2007;80(24-25):2303-2307.

75. Tyagi S, Tyagi P, Van-le S, et al. Qualitative and quantitative expression profile of muscarinic receptors in human urothelium and detrusor. J Urol. 2006;176(4 pt 1):1673-1678.

76. Mukerji G, YiangouY, Grogono J, et al. Localization of M2 and M3 muscarinic receptors in human bladder disorders and their clinical correlations. J Urol. 2006;176(1):367-373.

77. Grol S, Essers P, van Koeveringe GA, et al. M(3) muscarinic receptor expression on suburothelial interstitial cells. BJU Int. 2009;104(3): $398-405$. 
78. Kim Y, Yoshimura N, Masuda H, et al. Antimuscarinic agents exhibit local inhibitory effects on muscarinic receptors in bladder-afferent pathways. Urology. 2005;65(2):238-242.

79. de Wachter S, Wyndaele JJ. Intravesical oxybutynin: A local anaesthetic effect on bladder C afferents. J Urol. 2003;169:1892-1895.

80. Yokoyama O, Yusup A, Miwa Y, et al. Effects of tolterodine on an overactive bladder depend on suppression of C-fiber bladder afferent activity in rats. J Urol. 2005;174(5):2032-2036.

81. Iijima K, de Wachter S, Wyndaele JJ. Effects of the M3 receptor selective muscarinic antagonist darifenacin on bladder afferent activity of the rat pelvic nerve. Eur Urol. 2007;52(3):842-847.

82. de Laet K, de Wachter S, Wyndaele JJ. Systemic oxybutynin decreases afferent activity of the pelvic nerve of the rat: new insights into the working mechanism of antimuscarinics. Neurourol Urodyn. 2006 25(2):156-161.

83. Madersbacher H, Jilg G. Control of detrusor hyperreflexia by the intravesical instillation of oxybutynine hydrochloride. Paraplegia. 1991;29(2):84-90.

84. Lose G, Nørgaard JP. Intravesical oxybutynin for treating incontinence resulting from an overactive detrusor. BJU Int. 2001;87(9):767-773.

85. Ikeda K, Kobayashi S, Suzuki M, et al. M(3) receptor antagonism by the novel antimuscarinic agent solifenacin in the urinary bladder and salivary gland. Naunyn-Schmiedeberg's Arch Pharmacol. 2002;366(2):97-103.

86. Moriya H, Takagi Y, Nakanishi T, et al. Affinity profiles of various muscarinic antagonists for cloned human muscarinic acetylcholine receptor (mAChR) subtypes and $\mathrm{mAChRs}$ in rat heart and submandibular gland. Life Sci. 1999;64(25):2351-2358.
87. Watson N, Daniels DV, Ford AP, et al. Comparative pharmacology of recombinant human M3 and M5 muscarinic receptors expressed in CHO-K1 cells. Br J Pharmacol. 1999;127(2):590-596.

88. McNamara A, Pulido-Rios MT, Sweazey S, et al. Pharmacological properties of TD-6301, a novel bladder selective muscarinic receptor antagonist. Eur J Pharmacol. 2009;605(1-3):145-153.

89. Ohtake A, Saitoh C, Yuyama H, et al. Pharmacological characterization of a new antimuscarinic agent, solifenacin succinate, in comparison with other antimuscarinic agents. Biol Pharm Bull. 2007;30(1):54-58.

90. Nilvebrant L, Sundquist S, Gillberg PG. Tolterodine is not subtype (m1-m5) selective but exhibits functional bladder selectivity in vivo. Neurourol Urodyn. 1996;15:310-311.

91. Gillberg PG, Sundquist S, Nilvebrant L. Comparison of the in vitro and in vivo profiles of tolterodine with those of subtype-selective muscarinic receptor antagonists. Eur J Pharmacol. 1998;349(2-3):285-292.

92. Mansfield KJ, Chandran J, Vaux KJ, et al. Comparison of receptor binding characteristics of commonly used muscarinic antagonists in human bladder detrusor and mucosa. J Pharmacol Exp Ther. 2009;328(3):893-899.

93. Ito Y, Oyunzul L, Yoshida A, et al. Comparison of muscarinic receptor selectivity of solifenacin and oxybutynin in the bladder and submandibular gland of muscarinic receptor knockout mice. Eur J Pharmacol. 2009;615(1-3):201-206.
Open Access Journal of Urology

\section{Publish your work in this journal}

The Open Access Journal of Urology is an international, peer-reviewed, open access journal publishing original research, reports, editorials, reviews and commentaries on all aspects of adult and pediatric urology in the clinic and laboratory including the following topics: Pathology, pathophysiology of urological disease; Investigation and treatment of

\section{Dovepress}

urological disease; Pharmacology of drugs used for the treatment of urological disease. The manuscript management system is completely online and includes a very quick and fair peer-review system, which is all easy to use. Visit http://www.dovepress.com/testimonials.php to read real quotes from published authors. 